\title{
基点の温度が变動する場合の通気温度計算 に関する研究*
}

\author{
内 野 健 -1 井上雅 弘 $^{2}$ \\ 柳 本 竹 - 3
}

1. 緒言

坑内の通気温度を計算する場合, その通気の基点となる 場所の通気温度が一定であることはまれであり, 例えば, 入気坑口での大気温度は常に変動しているのが普通である。 また坑内においても通気系統の変更や泠却設備の設置など により, 基点の通気温度が急変することもある。したがつ て基点の温度変動が通気温度におよぼす影響を把握するこ とは, 通気温度予測計算における重要な課題の一つである が, まだ十分解明されているとは言い難い。すなわち，大 気温度の年変化や日変化を考慮する意味で, 基点の温度が 周期的変動をする場合の通気温度変化については, いくつ かの研究 ${ }^{1) ~ 3)}$ が発表されているが, 坑道モデルの設定, あ るいは解析上の仮定が必ずしも適当ではないと思われる箇 所がある。また, 基点の温度が急変する場合については, 現実に重要な問題であるにもかかわらず, これに関する研 究はほとんど行なわれていない。そこで筆者らは，まず， 通気の温度が時間の任意の関数として与えられる場合の坑 道周辺岩盤から放散される熱量に関する理論的研究 ${ }^{4)}$ を行 ない, その結果はすでに発表した。本報では, 基点の温度 が変動する場合の, 通気温度の時間的, 距離的変化につい て論じる。

本研究では, 通気温度と岩盤温度とを連立させて通気温 度を求めるために Lapl ace 変換を用い, まず, 基点の温度 が時間の任意の関数として变動する場合の, 通気温度の時 間的, 距離的変化を与える一般解を導いた。次にこれを基 にして, 基点の温度が周期的変動をする場合および急変す る場合の通気温度变化を与える式を求め, この数值計算を 行なつた。また, 得られた式はかなり複雑であるので近似 式を導き,この検討もあわせて行なつた。

\section{2. 基礎理論式}

まず坑道中のある地点を考え，これを基点とし，この基 点における通気温度が時間の任意の関数として与えられた

\footnotetext{
1981 年 4 月 16 日受理 昭和 54 年 6 月 9 日日本鉱業会九州支部春 季例会にて一部発表

1. 正会員 工博 九州大学助教授工学部資源工学科

2. 正会員 九州大学大学院 工学部資源工学科

3. 正会員 工博 九州大学教授 工学部資源工学科
}

場合の, 通気温度の時間的, 距離的変化を与える一般解を 求める。坑道周辺岩盤の広がりは無限て均質かつ等方性, 岩盤の熱物性值は岩盤温度に依存せず，初期温度分布は一 様, 坑道は水平でその断面は円形, 壁面における水の蒸発 および坑道軸方向の岩盤の温度勾配の影響が無視できるも のとすれば, 岩艋温度および通気温度についての基礎微分 方程式, 境界条件および初期条件は次のようになる。

$$
\begin{aligned}
& \frac{\partial^{2} \theta}{\partial r^{2}}+\frac{1}{r} \frac{\partial \theta}{\partial r}-\frac{1}{a} \frac{\partial \theta}{\partial t}=0 \\
& r=r_{0}: \quad \lambda \frac{\partial \theta}{\partial r}=\alpha(\theta-\Theta) \\
& r \rightarrow \infty: \theta=\theta_{v} \quad \ldots \ldots \ldots \ldots \ldots \ldots \ldots \ldots \ldots \ldots \ldots \ldots \ldots \ldots \ldots \ldots \ldots \ldots \ldots \ldots \\
& t=0: \theta=\theta_{v}
\end{aligned}
$$

ここで, $\theta$ : 岩盤温度 $\left({ }^{\circ} \mathrm{C}\right), \theta_{v}$ : 初期岩盤温度 $\left({ }^{\circ} \mathrm{C}\right)$, $\Theta$ : 通気温度 ( $\left.{ }^{\circ} \mathrm{C}\right), \Theta_{0}$ : 基点に打年通気温度 $\left[\Theta_{0}=\Theta_{0}\right.$ $(t)]\left({ }^{\circ} \mathrm{C}\right), t$ : 通気開始後の経過時間 $(\mathrm{h}), r$ : 坑道中心 から半径方向の距離 $(\mathrm{m}), r_{0}$ : 坑道半径 $(\mathrm{m}), z$ : 基点か らの坑道軸方向距離 $(\mathrm{m}), a$ : 岩盤の温度伝導率 $\left(\mathrm{m}^{2} / \mathrm{h}\right)$, $\lambda$ : 岩盤の熱云導率 $\left(\mathrm{kcal} / \mathrm{mh}^{\circ} \mathrm{C}\right) ， \alpha$ : 坑道壁面におけ 万熱伝達率 $\left(\mathrm{kcal} / \mathrm{m}^{2} \mathrm{~h}{ }^{\circ} \mathrm{C}\right) ， Q$ : 単位時間に坑道断面を通 過する空気の熱容量 $\left(\mathrm{kcal} / \mathrm{h}{ }^{\circ} \mathrm{C}\right)\left[Q=G \cdot C_{a}, G\right.$ : 風量= $\pi r_{0}^{2} v r_{a}(\mathrm{~kg} / \mathrm{h}), C_{a}$ : 空気の比熱 $\left(\mathrm{kcal} / \mathrm{kg}^{\circ} \mathrm{C}\right), v$ : 風 速 $(\mathrm{m} / \mathrm{h}), \gamma_{a}:$ 空気の密度 $\left.\left(\mathrm{kg} / \mathrm{m}^{3}\right)\right]$ 。

(1)〜6)式に含まれる変数を次のように無次元化する。

$$
\left.\begin{array}{lll}
\chi=\frac{\theta-\theta_{v}}{\theta_{r}-\theta_{v}} & \phi=\frac{\Theta-\theta_{v}}{\theta_{r}-\theta_{v}} & \xi=\frac{2 \pi \lambda}{Q} z \\
\rho=\frac{r}{r_{0}} & \tau=\frac{a}{r_{0}^{2}} t & \sigma=\frac{\alpha r_{0}}{\lambda}
\end{array}\right\} \cdot \cdot(7)
$$

ここで $\theta_{r}$ は適当に定められた示標温度 $\left(\theta_{r} \neq \theta_{v}\right)\left({ }^{\circ} \mathrm{C}\right)$ で ある。(7)式を用いて变数変換を行なえば, (1) (6)式は次の ようになる。

$$
\begin{aligned}
& \frac{\partial^{2} \chi}{\partial \rho^{2}}+\frac{1}{\rho} \frac{\partial \chi}{\partial \rho}-\frac{\partial \chi}{\partial \tau}=0 \\
& \rho=1: \frac{\partial \chi}{\partial \rho}=\sigma(\chi-\phi)
\end{aligned}
$$




$$
\begin{aligned}
& \rho \rightarrow \infty: \chi=0 \\
& \tau=0: \\
& \frac{\partial \phi}{\partial \xi}=\sigma\left(\chi_{\rho=1}-\phi\right) \\
& \xi=0: \phi=\phi_{0}
\end{aligned}
$$

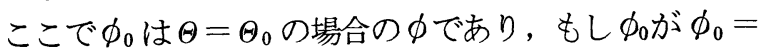
$\phi_{01}+\phi_{02}$ で与えられるときは, 上記の微分方程式の $\phi_{0}$ の代 わりに $\phi_{01}$ とおいて得られる解を $\phi_{1}, \phi_{02}$ とおいて得られる 解を $\phi_{2}$ とすれば，上記の微分方程式の解は $\phi=\phi_{1}+\phi_{2}$ と して与えられる。

(8)〜(13)式に対し Lapl ace 変換を行ない, 各変数の Lap l ace 変換を変数の上部に一をつけて表せば, 次のように なる。

$$
\begin{aligned}
& \frac{d^{2} \bar{\chi}}{d \rho^{2}}+\frac{1}{\rho} \frac{d \bar{\chi}}{d \rho}-s \bar{\chi}=0 \\
& \rho=1: \frac{d \bar{\chi}}{d \rho}=\sigma(\bar{\chi}-\bar{\phi}) \\
& \rho \rightarrow \infty: \bar{\chi}=0 \\
& \frac{d \bar{\phi}}{d \xi}=\sigma\left(\bar{\chi}_{\rho=1}-\bar{\phi}\right) \\
& \xi=0: \ldots \ldots \ldots \ldots \ldots \ldots \ldots \ldots \ldots \ldots \ldots
\end{aligned}
$$

ただし， $s$ は La p l ace 変換公式中の複素変数である。 (14) (18)式の微分方程式を解けば，历が次のように得られ る。

$$
\bar{\phi}=\bar{\phi}_{0} \exp \left\{-\frac{\sqrt{s} K_{1}(\sqrt{s}) \xi}{K_{0}(\sqrt{s})+\frac{\sqrt{s}}{\sigma} K_{1}(\sqrt{s})}\right\} \cdots(19)
$$

ここで $K_{0}, K_{1}$ はそれぞれ 0 次と 1 次の第 2 種変形Bessel関数である。

(19)式で表わされるあをBrnmwi ch 積分により逆変換 ${ }^{5)}$ すれば, 求めるめが得られる。

$$
\begin{gathered}
\phi(\tau, \xi)=\frac{1}{2 \pi i} \lim _{\beta \rightarrow \infty} \int_{\alpha-i \beta}^{\alpha+i \beta} \bar{\phi}_{0} \\
\quad \exp \left\{-\frac{\sqrt{s} K_{1}(\sqrt{s}) \xi}{K_{0}(\sqrt{s})+\frac{\sqrt{s}}{\sigma} K_{1}(\sqrt{s})}\right\} e^{s \tau} d s
\end{gathered}
$$

(20)式が基点の温度が時間の任意の関数として変動する場 合の通気温度変化を表す一般解である。同様の方法によ り，岩盤温度を表す解を求めることができるが，ここで は記述を省略する。

\section{3. 基点の温度が周期的変動をする場合}

\section{$3 \cdot 1$ 理論解}

基点の温度が次式で表される周期的変動をするものと する。

$$
\Theta_{0}=\Theta_{a} \sin (\omega t+\varepsilon)+\theta_{m}
$$

a) $\bar{\chi}(s)=\int_{0}^{\infty} e^{-s \tau} \chi(\tau) d \tau$
ここで, $\theta_{a}$ : 振幅 $\left({ }^{\circ} \mathrm{C}\right), \omega$ : 角速度 $(=2 \pi /$ 周期 $)(\mathrm{rad}$ $/ \mathrm{h}), \varepsilon$ : 位相 $(\mathrm{rad}), \theta_{m}:$ 平均温度 $\left({ }^{\circ} \mathrm{C}\right)$ 。

$\theta_{r}=\theta_{v}+\theta_{a}\left(\theta_{a} \neq 0\right)$ として(7)式を用いて変数変換すれ ば21)式は次のように表される。

$$
\begin{aligned}
& \phi_{0}=\sin (b \tau+\varepsilon)+\left(\theta_{m}-\theta_{v}\right) / \theta_{a} \\
& b=\omega r_{0}^{2} / a \\
& \text { (23) } \\
& \phi_{0}=\phi_{01}+\phi_{02} \\
& \phi_{01}=\sin (b \tau+\varepsilon) \\
& \phi_{02}=\left(\theta_{m}-\theta_{v}\right) / \theta_{a}
\end{aligned}
$$

と表すことができる。すなわち, 基点の温度が22式で与 えられるときの通気温度 $\phi$ は, 基点の温度が(25)式で与えら れる周期的変動をする場合 $\left(\phi_{01}\right)$ に対する解 $\phi_{1}$ と基点の 温度が(26)式で与えられる一定值を示す場合 $\left(\phi_{02}\right)$ に対する 解 $\phi_{2}$ との和, $\phi=\phi_{1}+\phi_{2}$ で与えられることがわかる。 基点の温度が一定の場合の解 $\phi_{2}$ は既にV an Heerden ${ }^{6)}$ に

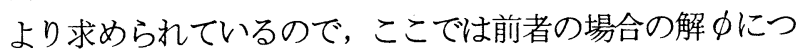
いて論じる。

(25)式を Lapl ace 変換すれば，

$$
\bar{\phi}_{01}=\frac{b \cos \varepsilon+s \sin \varepsilon}{s^{2}+b^{2}}
$$

(27)式を(20)式の $\bar{\phi}_{0} に$ 代入して積分すれば，通気温度 $\phi_{1}$ が 28式のように得られる。

$$
\begin{aligned}
& \phi_{1}(\tau, \xi)=\exp \left\{-S_{a} \cdot \xi\right\} \cdot \sin \left\{b \tau+\varepsilon-S_{b} \cdot \xi\right\} \\
& +\frac{2}{\pi} \int_{0}^{\infty} \exp \left\{-v^{2} \tau-\frac{D v \xi}{A^{2}+B^{2}}\right\} \sin \left\{\frac{\frac{2}{\pi} \xi}{A^{2}+B^{2}}\right\} \\
& \times \frac{b \cos \varepsilon-v^{2} \sin \varepsilon}{v^{4}+b^{2}} v d v
\end{aligned}
$$

ただし，

$$
\begin{aligned}
S_{a}= & \frac{\sqrt{b N_{1}}}{N_{c}} \cos \left(\Psi_{1}+\frac{\pi}{4}-\Psi_{c}\right) \\
S_{b}= & \frac{\sqrt{b N_{1}}}{N_{c}} \sin \left(\Psi_{1}+\frac{\pi}{4}-\Psi_{c}\right) \\
N_{c}= & \left\{N_{0}^{2}+\left(\frac{\sqrt{b}}{\sigma} N_{1}\right)^{2}+2 \frac{\sqrt{b}}{\sigma} N_{0} N_{1}\right. \\
& \left.\times \cos \left(\Psi_{0}-\Psi_{1}-\frac{\pi}{4}\right)\right\}^{1 / 2} \\
\Psi_{c}= & \tan { }^{-1}\left[\left\{N_{0} \sin \Psi_{0}+\frac{\sqrt{b}}{\sigma} N_{1} \sin \left(\Psi_{1}+\frac{\pi}{4}\right)\right\}\right. \\
& \left.\left\{N_{0} \cos \Psi_{0}+\frac{\sqrt{b}}{\sigma} N_{1} \cos \left(\Psi_{1}+\frac{\pi}{4}\right)\right\}\right] \\
A= & J_{0}(v)+\frac{v}{\sigma} J_{1}(v) \\
B= & Y_{0}(v)+\frac{v}{\sigma} Y_{1}(v) \\
D= & J_{1}(v) A+Y_{1}(v) \cdot B \\
K_{0} & (\sqrt{i b})=N_{0} e^{i \psi_{0}}
\end{aligned}
$$


Table 1 Constant values used in calculation

\begin{tabular}{l|l|l|l}
\hline$r_{o}$ & $2.0(\mathrm{~m})$ & $\epsilon$ & $0.0(\mathrm{rad})$ \\
$\lambda$ & $1.8\left(\mathrm{kcal} / \mathrm{mh}^{\circ} \mathrm{C}\right)$ & $C a$ & $0.24\left(\mathrm{kcal} / \mathrm{kg}^{\circ} \mathrm{C}\right)$ \\
$a$ & $3.29 \times 10^{-3}\left(\mathrm{~m}^{2} / \mathrm{h}\right)$ & $v$ & $18,000(\mathrm{~m} / \mathrm{h})$ \\
$\alpha$ & $18.0\left(\mathrm{kcal} / \mathrm{m}^{2} \mathrm{~h}^{\circ} \mathrm{C}\right)$ & $\gamma a$ & $1.13\left(\mathrm{~kg} / \mathrm{m}^{3}\right)$ \\
$\omega$ & $7.17 \times 10^{-4}(\mathrm{rad} / \mathrm{h})$ & & \\
\hline
\end{tabular}

$K_{1}(\sqrt{i b})=N_{1} e^{i \psi_{1}}$

また， $J_{0}, J_{1}, Y_{0}, Y_{1}$ はそれぞれ 0 次と 1 次の第 1 種お よび第 2 種 Bessel 関数である。

(28)式はかなり複雑であるが，てが大きくなると式中の被 積分関数の值が次第に小さくなるので， $\phi_{1}$ は近似的に次 のように簡単な式で表わされるようになる。

$\phi_{1}(\tau, \xi)=\exp \left(-S_{a} \xi\right) \cdot \sin \left(b \tau+\varepsilon-S_{b} \xi\right) \cdots(29)$

すなわち, 経過時間が長くなると通気温度 $\phi_{1}$ は一定周 期 $(=2 \pi / b)$ で同じ状態をくり返すようになる。

\section{$3 \cdot 2$ 計算結果}

通気温度 $\phi_{1}$ を計算する場合, (28)式の右辺に含まれる積分 を行なわなければならないが，これを解析的に行なうのは 極めて困難であるのでSimpson法による数值積分を用い た。なお，この方法は前報と基本的には同様であるので， その詳細は省略する。

$r_{0}, a, \lambda, \alpha, \omega, \varepsilon, C_{a}, v, r_{a}$ にTable 1 に示す值を与え た場合の計算を行なう。この場合， $b=0.8727, \sigma=20$ となり, また無次元距離 $\xi$ は $\xi=1.0$ がおよそ $5,000(\mathrm{~m})$ に相当し，時間 $\tau$ は $\tau=7.2$ がおよそ 1 (年) に相当する。

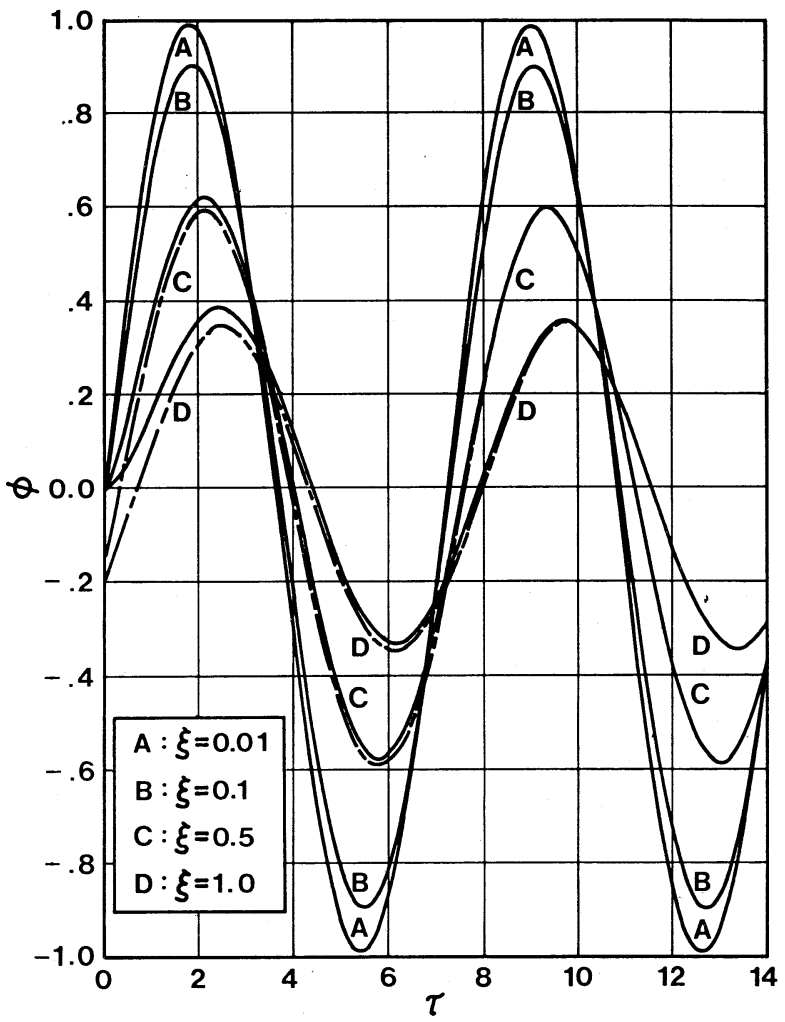

Fig. 1 Behavious of air temperature $\phi, \tau$ with the sinusodial variation of air temperature at the entrance.
上記の条件の場合の通気温度 $\phi_{1}$ の時間的変化を, 無次元 距離 $\xi$ をパラメータとして Fig. 1 に示す。また, 比較のため に， $\xi=0.5$ および $\xi=1.0$ の場合については29式による $\phi_{1}$ の計算結果を一点鎖線で示しているが， $\xi=0.01$ およ び $\xi=0.1$ の場合は28式による計算結果とほぼ同一であり, 図中では実線と一致する。

この結果によれば, 通気温度はまず過渡的状態を経て, 次第に周期的変動をするようになることがわかる。また， 基点からの距離 $\xi$ が大きくなるにしたがつて, 通気の温度 変化の振幅が小さくなり，位相が遅れることがわかる。例 えば $\xi=1.0$ の場合, 通気の温度変化の振幅は, 基点の温 度変化の振幅の $40 \%$ 程度であり, 位相の遅れは 0.7 (およ そ 1 力月に相当する ) 程度である。すなわち, 坑内深部箇 所の通気温度が最も高くなる時期は, 入気坑口からの距離 や風量にもよるが，大気温度が最も高くなる時期よりも遅 く, またその変化も大気温度の変化に比べて小さいことが わかる。

(28)式による $\phi_{1}$ の值と29)式による近似值とを比べると， $\xi$ $=0.01, \xi=0.1$ の地点では前述のように, 経過時間のご く初期から両者の差は無視できる程に小さいが, $\xi=0.5$,

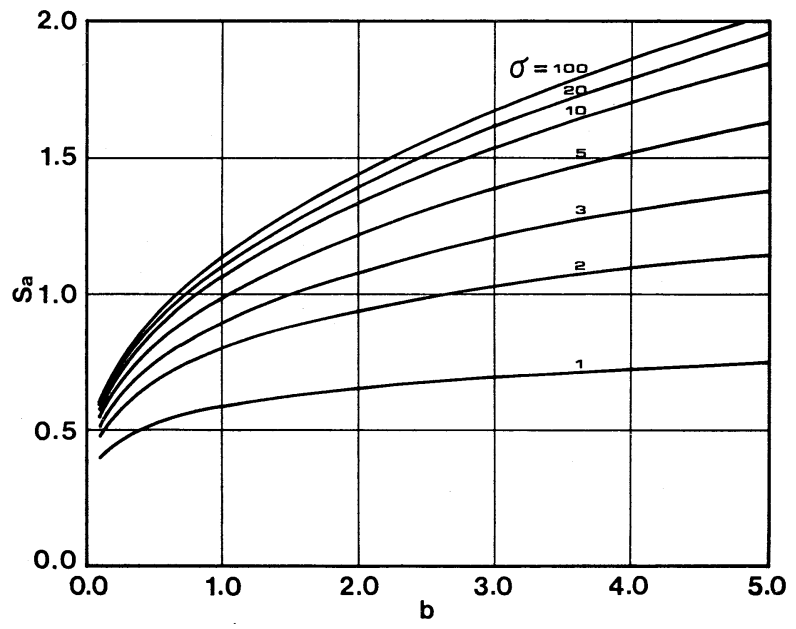

Fig. 2 The $S_{a}-b$ relationship for various Biot numbers $\sigma$.

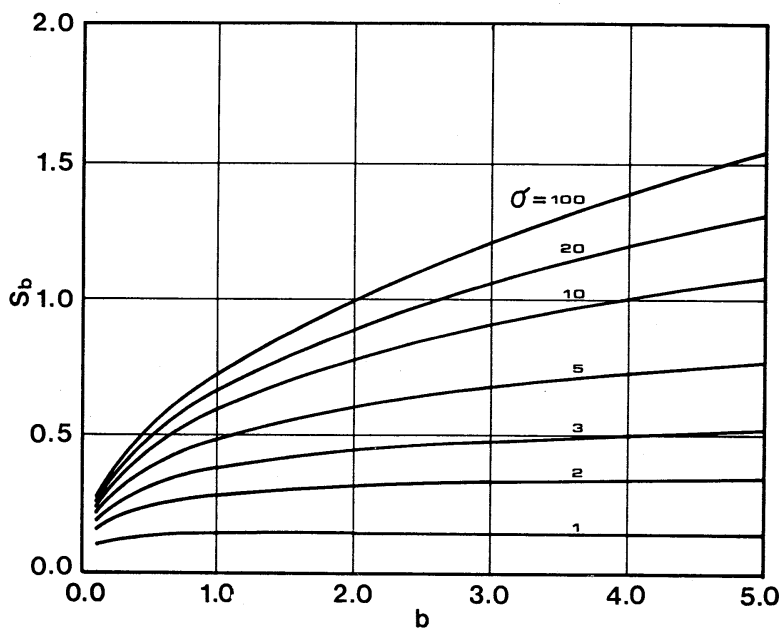

Fig. 3 The $S b-b$ relationship for various Biot numbers $\sigma$.

日本鉱業会誌/98 $1131\left({ }^{\prime} 82-5\right) \quad 407<17>$ 
$\xi=1.0$ に対する值が示すように，距離が大きくなると， 通気開始直後は両者の差が大きい。しかしながら，これら の大きい距離についても経過時間が $\tau=7.2$ (ほぼ 1 年に 相当する) 程度以上になれば, 両者の差は小さくなる。し たがつて，距離が $\xi<0.5$ であれば，経過時間にかかわら ず29式を用いて $\phi_{1}$ を求めても精度のよい值が得られるが, 距離が $\xi>0.5$ の場合には, 経過時間 1 年以内では28式を 用いるべきであり， 1 年以降は29式を用いてもよいといえ る。

Fig. 2 およびFig. 3 は29式により近似的に $\phi_{1}$ を求める際 に必要な保数 $S_{a}$ および $S_{b}$ の值を, Biot 数 $(\sigma)$ をパラメ

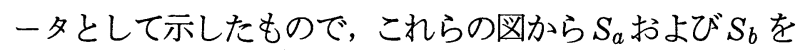
求めて29式に代入することにより, 容易に通気温度を計算 することができる。 $S_{a}$ は通気温度変動の大きさが,距離と ともに減少する割合を示す保数である。Fig. 2 より， bが 大きく( 周期が短く) なると， $S_{a}$ は大きくなつているので, 基点の温度変動の周期が短い程, 通気温度変動の減衰が大 きいことがわかり，したがつて入気温度の日変化の影響は, 年変化の影響に比べて小さいことがわかる。

本項では基点の温度が22式で表されるような, ある平 均温度を中心とした周期的变動をする場合に, この温度変 動の周期的成分による通気温度変動について述べたが，実 際の值を知るには, 28式あるいは29式で表される解に， 基点の温度の周期的変動の平均値 $(=$ cons t. $)$ による通気 温度変化を合成しなければならない。

\section{4. 基点の温度が急変する場合}

\section{1 理論解}

基点の温度がある時刻 $\left(t=t_{1}\right)$ までは $\Theta_{1}(=$ const. $)$

であるが, 時刻 $t_{1}$ で急変し $\Theta_{2}(=$ const. ) となり, これ以 後 $\Theta_{2}$ に保たれる場合を考える。すなわち， 基点の温度が

$$
\Theta_{0}=\left\{\begin{array}{ll}
\Theta_{1} \text { ( const.) } & 0<t<t_{1} \\
\Theta_{2} \text { (const.) } & t_{1}<t
\end{array} \ldots(30)\right.
$$

で表される場合である。

$$
\Theta_{r}=2 \Theta_{v}-\Theta_{2}\left(\Theta_{2} \neq \theta_{v}\right) \text { とおいて }(7) \text { 式 }
$$
を用いて変数变換すれば， 30 式は次のよう に表される。

$$
\phi_{0}=\frac{\Theta_{1}-\theta_{v}}{\theta_{v}-\Theta_{2}}+\frac{\Theta_{2}-\Theta_{1}}{\theta_{v}-\Theta_{2}} u\left(\tau-\tau_{1}\right)
$$

ここで, $\tau_{1}=a t_{1} / r_{0}^{2}, u(\tau)$ : 単位ス テップ関数。

(31)式を Lapl ace 変換し，(20)式の $\bar{\phi}_{0}$ に代

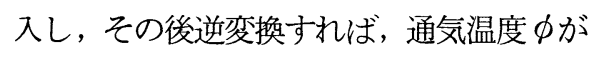
(32)式のように得られる。

$$
\phi(\tau, \xi)=\frac{\Theta_{1}-\theta_{v}}{\theta_{v}-\Theta_{2}} \cdot P(\tau, \xi)
$$

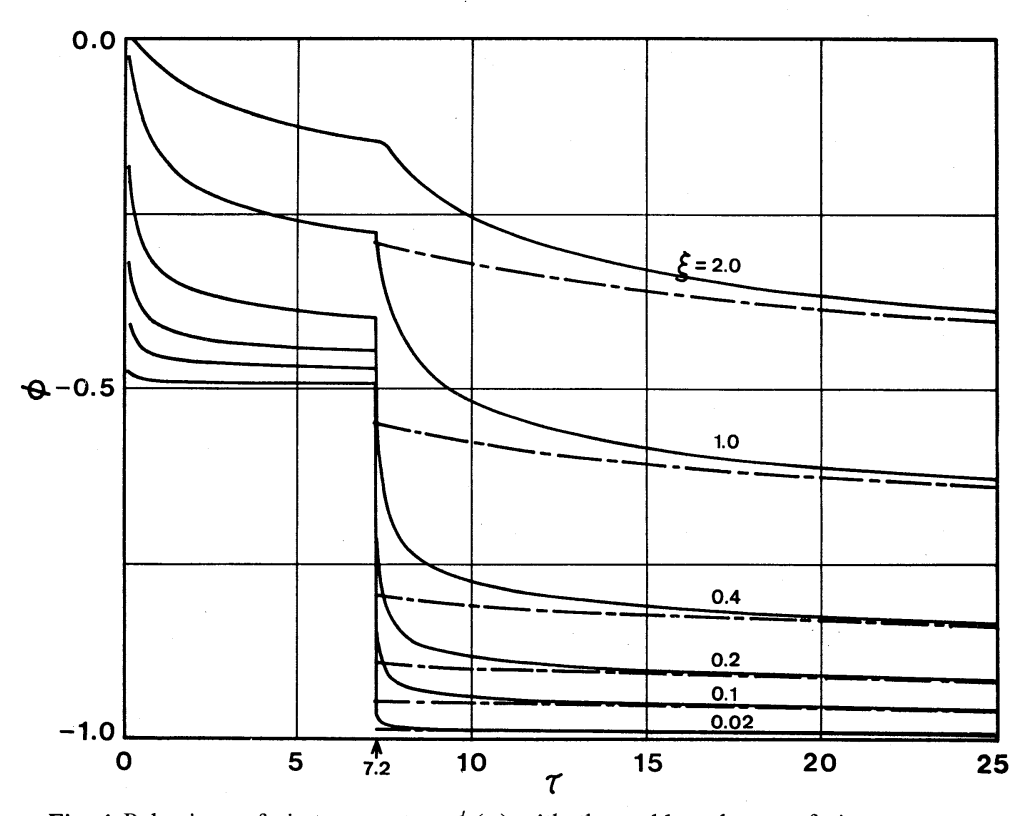

Fig. 4 Behaviour of air temperature $\phi(\tau)$ with the sudden change of air temperature when $\tau=7.2$ at the entrance.

$$
\begin{gathered}
+\frac{\Theta_{2}-\Theta_{1}}{\theta_{v}-\Theta_{2}} u\left(\tau-\tau_{1}\right) \cdot P\left(\tau-\tau_{1}, \xi\right) \quad \ldots \ldots \text { (32) } \\
P(\tau, \xi)=1-\frac{2}{\pi} \int_{0}^{\infty} \exp \left(-v^{2} \tau-\frac{D \cdot v \cdot \xi}{A^{2}+B^{2}}\right) \\
\quad \sin \left(\frac{\frac{2}{\pi} \cdot \xi}{A^{2}+B^{2}}\right) \frac{d v}{v} \quad \ldots \ldots \ldots \ldots \ldots \ldots \ldots \ldots(33)
\end{gathered}
$$

ここで, $P(\tau, \xi)$ は,時刻 $\tau=0$ において基点の温度が 0から単位大きさに変化し，その後その大きさに保たれる 場合に, その変化の影響が時間的・距離的にどのように伝 えられるかを表す関数である。

また, 基点の温度の急変が複数回起こつた場合であつても, その変化は(31)式と同様な形式で表され, 通気温度 $\phi$ も容 易に(32)式と類似の形で表すことができる。しかし後述す るように, 通常の条件下では, 急変後の通気温度に及ぼす 急変前の基点の温度の影響は, かなり急速に小さくなるの で, 実用的には, すべての急変を考慮する必要のある場合 は少ないと考えられる。

\section{$4 \cdot 2$ 計算結果}

通気温度 $\phi$ 計算する場合，(33)式中に含まれる無限積分 を行なわなければならないが, これも解析的に行なうのは 極めて困難なので, Simpson 法による数值積分を用いた。 被積分関数は $v$ が 0 に近づくにつれて絶対值が大きくなり, $v=0$ では定義されないので, $v=0$ の近傍では数值積 分によらず，解析的に近似積分を行なつた。またvが大き くなると, 被積分関数は非常に小さくなり, あるvの值以 上ではほとんど無視できるようになる。したがつて, 積分 範囲 $[0, \infty]$ を解析的積分範囲 $\left[0, v_{1}\right]$, 数值積分範囲 $\left[v_{1}, v_{2}\right]$ ，および積分值が無視できる範囲 $\left[v_{2}, \infty\right]$ に分 けて積分を行なつた。ただし $v_{1}, v_{2}$ には次の条件を満足す 
る值を用いた。

$$
\begin{aligned}
& v_{1}=\operatorname{MIN}[0.06,0.07 / \sqrt{\tau}] \\
& v_{2}=4.0 / \sqrt{\tau}
\end{aligned}
$$

$\left[0, v_{1}\right]$ の積分值を $I$ とおけば

$$
I=\int_{0}^{v_{1}} \exp \left(-v^{2} \tau-\frac{D v \xi}{A^{2}+B^{2}}\right) \sin \left(\frac{\frac{2}{\pi} \xi}{A^{2}+B^{2}}\right) \frac{d v}{v}
$$

(35)

被積分関数を展開し，vの 2 次以上の項を省き，さらに 変数変換を行なえば,

$$
I=\frac{\pi}{2} \int_{x_{1}}^{\infty} \exp \left(-\frac{\frac{2}{\pi} \cdot x \cdot \xi}{1+x^{2}}\right) \sin \left(\frac{\frac{2}{\pi} \cdot \xi}{1+x^{2}}\right) d x(36)
$$

ただし，

$$
\begin{aligned}
& x_{1}=-\frac{2}{\pi}\left(\gamma+\log _{\mathrm{e}} \frac{v_{1}}{2}-\frac{1}{\sigma}\right) \\
& \gamma: \text { Eulerの定数 }(\div 0.5772)
\end{aligned}
$$

(36)式をさらに展開し, 要求精度に必要な項までの積分を 行なうことで, $I$ の值を求めることができる。

Table 1 と同じ条件で, $\left(\Theta_{1}-\theta_{v}\right) /\left(\theta_{v}-\Theta_{2}\right)$ を- 0.5 , 基点の温度の急変時刻 $t_{1}$ を 1 年 $\left(\tau_{1}=7.2\right)$ とした場合の 通気温度 $\phi$ の変化を, 距離 $\xi$ をパラメータとしてFig. 4 に 示す。また同図中の一点鎖線は, 基点の温度の急変は起こら ず, 通気開始時から一定温度 $\Theta_{2}$ であるとした場合の通気温 度変化を示している。

Fig.4によれば, 基点の温度が急変したあとの坑道の各 点における通気温度の時間的な変化を知ることができる。 基点からの距離が小さい地点では, 図中の $\xi=0.2 \sim 1.0$ の曲線が示すように, 基点の温度の急変直後は通気温度の 変化がいちじるしいが, その後, 時間の経過とともにゆる やかになる。一方, 基点から相当離れた地点では, 図中の $\xi=2.0$ の曲線が示すように, 基点の温度の急変直後もゆ るやかな変化しか示さない。このように, 基点の温度変化 の影響のあらわれ方は, 基点からの距離によつて異なるこ とがわかる。その物理的意味は次のように考えることがで きる。すなわち，いま基点の温度が急に低下したとすると， 基点近くではすぐにその低下した温度の影響を受ける。一 方, 通気温度が低下寸ると, 坑道壁面と通気の温度差が大 きくなり，いままでより多くの熱が通気に与えられるよう になり,この結果, 通気の温度上昇が大きくなる。このた め, 距離が増加すると基点の温度低下の影響が小さくなる のである。また基点温度がクーラによつて低下したと考え れば, Fig.4から冷却効果の違いも知ることができる。つ まり, クーラからの距離が大きくなると, 冷却効果は小さ くなり，その効果もすぐには現れない。クーラの設置箇所 を定めるという立場からいえば，できるだけ冷却の必要な 場所近くに設置すべきであるということになる。

つぎに，基点の温度の急变を考慮しなかつた場合の値と，

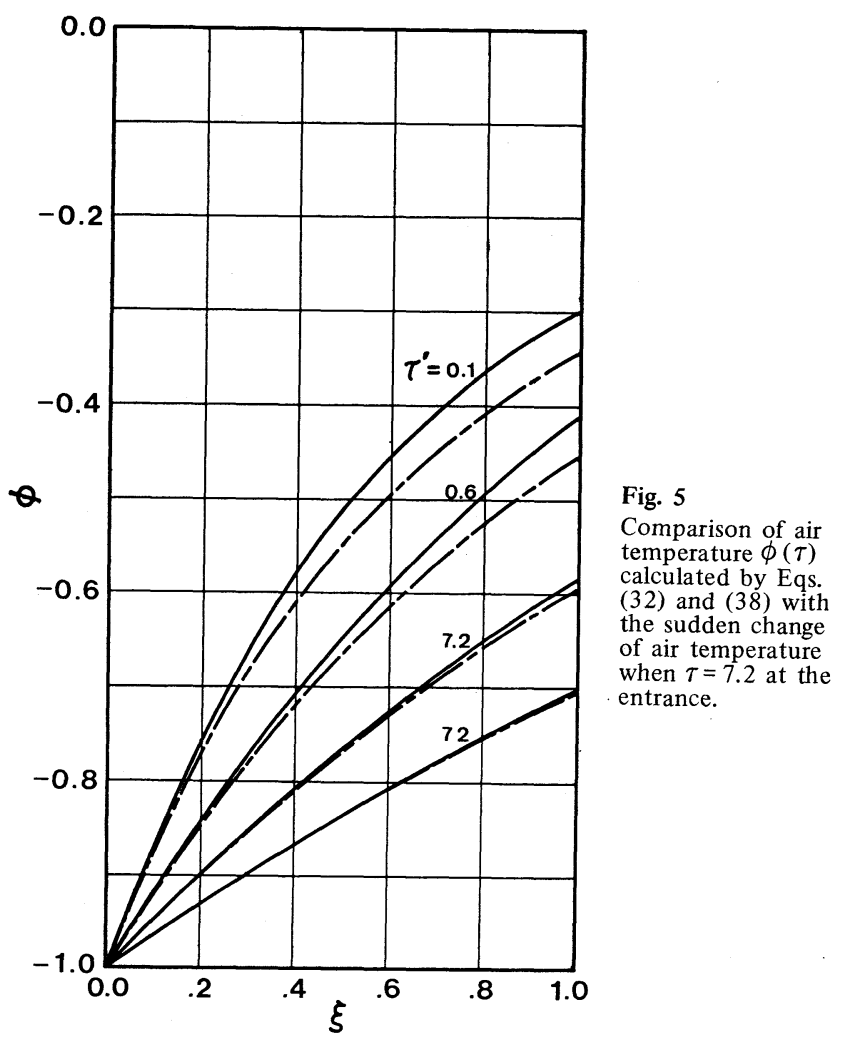

急変を考慮した場合の值を比較すると, 両者は急変してか らの経過時間が長くなればほとんど一致するようになる。 つまり, 距離 $\xi$ につてその程度は異なるが, 急変後 1 年 以上時間が経過した場合については, 実用的には, 基点の 温度の急変を考慮せず, はじめから急変後の温度であつた として計算してよいことになる。

以上, 厳密解に基づいて論じたが, 次に $K$ 值式 ${ }^{7)}$ とよば れる通気温度の近似計算式を応用した, 基点の温度の急変 後の通気温度変化を考える。

$K$ 值式によれば, 時刻 $\tau=0$ において基点の温度 $\phi_{0}$ が 0 から 1 に変化したときの通気温度 $\phi$ は次のように表され る。

$$
\phi=\exp (-K \xi)
$$

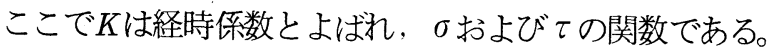
(37)式を(33)式の代わりに(32式に代入すれば次式を得る。

$$
\phi=\frac{\Theta_{1}-\theta_{v}}{\theta_{v}-\Theta_{2}} \exp \left(-K_{1} \xi\right)+\frac{\Theta_{2}-\Theta_{1}}{\theta_{v}-\Theta_{2}} \exp \left(-K_{2} \xi\right)
$$

この場合， $K_{1}$ は通気開始時からの経過時間に対応する 経時俰数であり, $K_{2}$ は基点の温度の急变時からの経過時 間に対応する経時保数である。

Fig. 5 はFig. 4 の場合と全く同じ条件を与えたときの(32) 式の厳密解による通気温度と(38)式の近似解による通気温度 を示している。実線は厳密解, 一点鎖線は近似解による通 気温度で, パラメータ $\tau^{\prime}=\tau-\tau_{1}$ は, 急变してからの経 過時間を示す。図より距離が小さい程両者の差が小さく， 
また経過時間が長くなる程両者の差が小さくなることがわ かる。したがつて, 実用的には, 基点の温度の急変時から の経過時間が 1 年以上であれば，(38)式を用いて通気温度を 求めてもさしつかえないと考えられる。

\section{5. 結言}

本報においては，坑内通気温度計算に関する基礎研究と して，基点の通気温度が時間的に任意の変動をする場合の， 通気温度の時間的, 距離的変化を与える一般解を求め, こ れより, 基点の温度が周期的変動をする場合および急変す る場合の通気温度変化をあらわす解を導き, 数值計算を行 ない, いくつかの検討を加えた。

基点の温度が周期的変動をする場合, 通気温度はまず過 渡的状態を経て，周期的変動をするようになるが，基点か ら遠ざかるにしたがつて, その変動の振幅が小さくなり， 位相の遅れが大きくなる。過渡的状態を考慮せねばならな い時間は, 距離によつて異なるが, 通常の状態では通気開 始時から 1 年以上の時間が経過すれば， $5,000 \mathrm{~m}$ 程度の距 離においても，積分項を無視した(29)式で十分近似できると 考えられる。

基点の温度が急変する場合には, 基点に近い程, 通気温 度の変化が急であるが, 距離が大きくなると, 急変の影響
が顕著になるまでにかなりの時間を要するようになる。こ の場合についても近似的取扱いが可能であり，一つは急変 を無視する方法で, Fig. 4 に示すように，急変前の基点の 温度の影響は比較的短時間で無視できることがわかる。ま た，他の一つは $K$ 值式を応用する方法で，これは簡単な方 法であるが，急変時刻から 1 年以上経過すれば，Fig. 5 に 示すように実用的に十分な精度をもつと考えられる。

本研究では坑道は乾いているものとして計算を行なつた が，湿つた坑道については別に詳しく論じる計画である。

なお, 本報で述べた計算には九州大学大型計算機センタ 一, FACOM M-200を用いた。

\section{参考文 献}

1）平松良雄・小門純一：日本鉱業会誌， 75 [857]，17～21， (1959)

2）天野勲三：日本鉱業会誌，70 [787]，23～26, (1954)

3）橋本文作：日本鉱業会誌，71[809]，9～15，(1955）

4）井上雅弘 - 内野健一 - 柳本竹一：日本鉱業会誌，97[1120]，31 $\sim 36, \quad(1981)$

5) H. S. Carslaw \& J. C. Jaeger : Conduction of Heat in Solids, Oxford, 2nded.

6) C. Van Heerden: Proceedings of The General Discussion on Heat Flow, Inst. Mech. Eng., 283 285 . (1961)

7）内野健一：日本鋑業会合同秋季分科研究会，（1974）

\title{
Theoretical Calculation of Temperature of Ventilation Air with Varying Air Temperature at the Entrance
}

\author{
by Ken-ichi UCHINO ${ }^{1}$, Masahiro INOUE $^{2}$ and Takeichi YANAGIMOTO ${ }^{3}$
}

In predicting the temperature of ventilation air in practice, it is necessary to take into consideration the variation of air temperature at the entrance, caused by atmospheric conditions and artificial ones such as the change of ventilation net work and the installation of cooling units. In the present paper the effect of variation of the air temperature at the entrance on the air temperature along the roadway are theoretically analysed.

A general expression, Eq. (20), is first obtained for the temperature along the roadway when the air temperature at the entrance changes arbitrarily. Then numerical values of Eq. (20) are calculated for two practical cases: sinusodial and sudden changes of the temperature at the entrance. Results of the discussion are as follows;

(a) In the case of the sinusoidal air temperature change at the entrance, the temperature of ventilation air shows a transient state at the beginning of ventilation, but then reaches some sinusodial state of variation which is expressed by Eq. (29). The amplitude is reduced and the phase delayed as the distance from the entrance increases. The temperature of ventilation air can be approximated by Eq. (29) after about one year from the start of ventilation.

(b) The effect of a sudden air temperature change at the entrance is instantaneous on the temperature of ventilation air at a short distance from the entrance and is gradual as the distance increases. Two practical approximate equations for this case are proposed.

(1. Assoc. Prof., Dr., Faculty of Engineering, Kyushu Univ.

3. Prof., Dr., Faculty of Engineering, Kyushu Univ.

2. Graduate Student, Kyushu Univ. )

\begin{tabular}{|c|c|c|c|c|c|}
\hline \multicolumn{2}{|c|}{ 昭和 56 年度講習会資料 } & \multicolumn{4}{|c|}{ 丈採鉱に関連する計測技術 } \\
\hline \multicolumn{2}{|c|}{57 年 1 月 26 日発行 } & $\|$ & (1) & 爆薬・爆破に関する計測……………………........花崎 & 紘一 \\
\hline \multirow{4}{*}{$\begin{array}{l}\text { 主 催 } \\
\text { 協 替 }\end{array}$} & \multirow{4}{*}{$\begin{array}{l}\text { 日本鉱業会関西支部 } \\
\text { 鉱業労働災害防止協会大阪支部 }\end{array}$} & 目 & $(2)$ & 地圧制御のための諸計測………………………...斎藤 & 敏明 \\
\hline & & 次 & (3) & 坑内支保に関する計測…………………………...松本 & 義雄 \\
\hline & & 11 & & 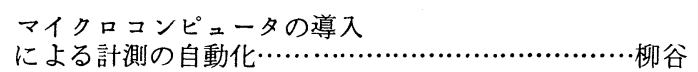 & 俊 \\
\hline & & & (5) & 最近の各種計測技術………………………….....藤中 & 雄三 \\
\hline
\end{tabular}

